Научная статья

УДК 616.31

DOI: $10.18101 / 2306-1995-2021-1-58-61$

\title{
СОВРЕМЕННЫЙ ВЗГЛЯД НА ФЛЮОРОЗ
}

\section{(C) Намханов Вячеслав Валентинович}

кандидат медицинских наук, доцент, Бурятский государственный университет имени Доржи Банзарова Россия, 6700002, г. Улан-Удэ, ул. Октябрьская, 36а namhanov@yandeex.ru

\author{
(C) Писаревский Юрий Леонидович \\ доктор медицинских наук, профессор, \\ заведующий кафедрой ортопедической стоматологии, \\ Читинская государственная медицинская академия \\ Россия, 672038, г. Чита, ул Новобульварная, 163 \\ ypisarevskij@mail.ru
}

Аннотация. Статья посвящена гистопатологической характеристике флюороза - поражения зубной эмали, связанного с постоянным и длительным попаданием в организм избыточного количества фтора. Отмечается, что флюороз носит эндемический и профессиональный характер. В тяжелых случаях сопровождается поражением костной ткани скелета. Наиболее часто флюороз отмечается при прорезывании постоянных зубов, у молочных зубов практически не встречается. Начинается флюороз с белесоватых пятен, которые с годами приобретают желтый оттенок. В статье описаны современные методы лечения флюороза, выбор которых зависит от клинических проявлений в области зубов, дана классификация, рассмотрены методы профилактики. Дана общая характеристика содержания фтора в водоисточниках Республики Бурятия.

Ключевые слова: флюороз, фтор, лицевой скелет, зубочелюстная система, верхняя челюсть, нижняя челюсть, зубы, эмаль, гигиена, полость рта, воспаление, костная ткань

\section{Для цитирования}

Намханов В. В., Писаревский Ю. Л. Современный взгляд на флюороз // Вестник Бурятского государственного университета. Медицина и фармация. 2021. № 1. C. $58-61$.

Актуальность проблемы флюороза зубов существует и в настоящее время. Понятие «флюороз зубов» описан во всем мире. В начале XX в. стало известно, что причиной является избыток фтора в воде и имеется более 500 мест на Земле с очагами флюороза.

Фтор поступает в организм человека как с продуктами $(1,0-1,6$ мг), так и водой (2,5-3,0 мг). С продуктами фтор всасывается меньше, чем с водой. Известно, что фтор выделяется через потовые железы и почками, а часть задерживается в организме. В воде концентрация фтора по правилам госстандарта допускается до 2 мг/л, но и при таком стандарте может иметь место флюороз. В соответствии с государственными стандартами определена допустимая концентрация фтора в водоисточнике 1,5 мг/л. Следует отметить, что при такой концентрации часто отмечается флюороз 
зубов. При концентрации фтора в воде - 1,0-1,5 мг/л наблюдается флюороз у $30 \%$ населения, при 1,5-2,0 мг/л - 30-40\%, при 2,0-3,0 мг/л у 80-90\% населения эндемического района.

За 2020 год концентрация фтора в воде в различных районах Бурятии неодинакова. Так, например, наибольшее содержание фтора в воде выявлено в Тарбагатайской районе и составляет 0,95 мг/дм, в Муйском районе - 0,70 мг/дм, в Прибайкальском районе - 0,66 мг/дм, в Заиграевском и Селигинском районах - по 0,65 мг/дм. В г. Улан-Удэ среднее содержание фтора в воде составляет 0,53 мг/дм.

Этиология флюороза, воздействие на эмаль еще до конца не изучены. На изменение амелобласта, остановку развития эмалевых призм может привести токсическое действие фтора.

В районах с повышенным содержанием фторакак с легким изменением зубов имеются, в большинстве случаев значительные клинические поражения зубов. Это говорит о том, что это зависит от реактивности организма, возраста, иммунитета.

За 2019-2020 гг. (1 кв.) нами было осмотрено более 100 пациентов с флюорозом в возрасте 20-40 лет. Из них 42 пациента были с умеренной степенью (пятнистая форма флюороза), 43 поциента с флюорозом средней степени тяжести (меловиднокрапчатая форма), 5 пациентов с тяжелой степенью тяжести (эрозивная форма).

Лечение флюороза зависит от клинических проявлений в области зубов. Начинают полную санацию полости рта и профилактические мероприятия.

В начальной стадии флюороза применяют аппаратные методы отбеливания. Существуют различные методы отбеливания зубов в условиях стоматологического кабинета, все они основаны на использовании высококонцентрированного раствора или геля перекиси водорода. Мы в своей практике использовали такие материалы, как Opalescence Xtra ETNTERPRISE Co., Ltd. (TAIWAN), при этом получены положительные результаты. Более яркие пятна до отбеливания снимали за счет микроабразии эмали. Результаты отбеливания оценивали спустя 2-3 дня. К основным недостаткам отбеливания можно отнести тот факт, что результат не является постоянным и требует периодически поддерживающей терапии. Появление повышенной чувствительности зубов после отбеливания у пациентов с флюорозом мы отмечали в $5 \%$ случаев.

По нашим наблюдениям, в первые часы после процедуры восстанавливать цвет и форму зуба современными пломбировочными материалами следует все же после предварительного отбеливания.

Всем пациентам с тяжелой формой изготавливали виниры прямым методом и при необходимости ортопедические конструкции (коронки).

При протезировании зубов, поврежденных флюорозом, предварительно нужно провести процедуру отбеливания, так как светлые зубы имеют натуральный оттенок.

Данным больным в процессе чистки зубов рекомендуют зубные пасты с большим содержанием кальция. Фтора не должно быть, внимательно читать аннотацию.

Если имеются районы с большим содержанием фтора в воде, нужно проводить профилактику, а именно - очистку воды в населенных районах, особенно в детских садах, школах, средних и высших учебных заведениях.

При индивидуальных методах профилактики рекомендуется:

- вскармливание грудью;

- применение витаминов группы В, С; глюконата кальция; 
- исключение и ограничение продуктов с содержащих фтора;

- летние и спортивные лагеря для детей.

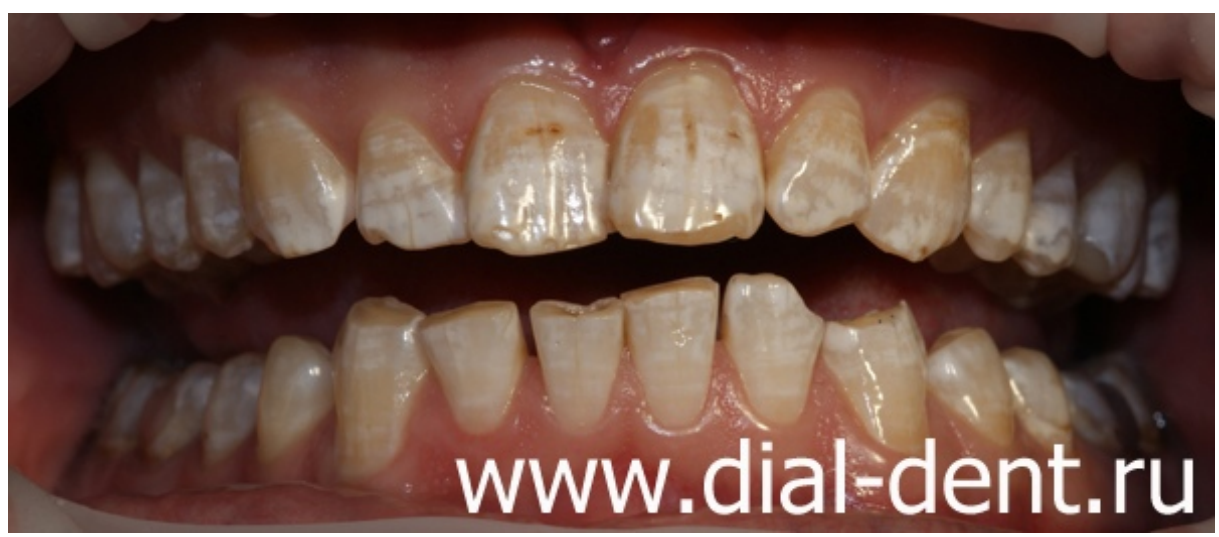

Рис. 1. Флюороз эндемический

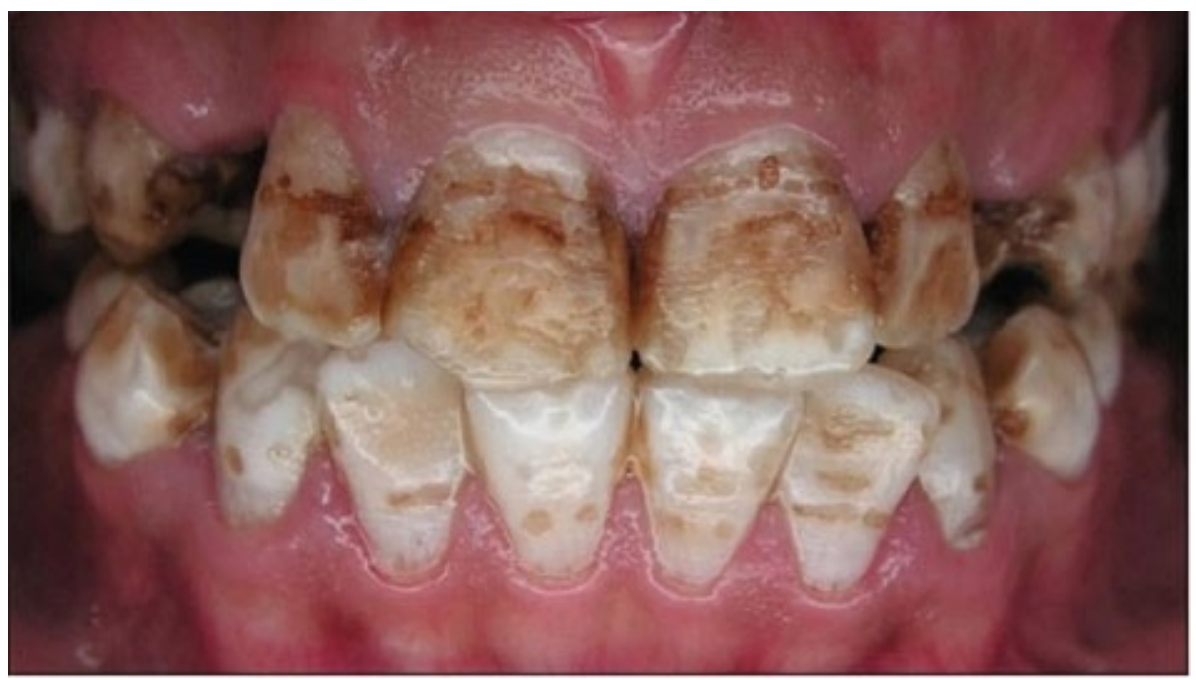

Рис. 2. Флюороз эрозивный

Лuтература

1. Воронов Н. И., Базикян Э. А., Пихлак У. А. Оценка состояния тканей пародонта у женщин в постменопаузальном периоде в зависимости от значений минеральной плотности костной ткани скелета // Медицина критических состояний. 2019. № 4. С. 30-33. Текст: непосредственный.

2. Определение рентгеноморфометрических индексов нижней челюсти, по данным ортопантомографии и дентальной объемной томографии / С. М. Николаев [и др.] // Институт стоматологии. 2018. Т. 2, № 31. С. 87-92. Текст: непосредственный.

3. Новикова С. С. Оценка стоматологического статуса у женщин в постменопаузальном периоде в зависимости от минеральной плотности костной ткани скелета: автореферат диссертации на соискание ученой степени кандидата медицинских наук. Москва, 2017. 17 с. Текст: непосредственный. 
6. Саломатов Д. В. Спиральная компьютерная томография при заболеваниях челюстнолицевой области. Москва: МЕДпресс-информ. 2017. 67 с. Текст: непосредственный.

7. Сергеев М. Ю. Флюоороз у женщин // Современная стоматология. 2019. № 3. С. 27-31. Текст: непосредственный.

8. Пономоренко И. М. Флюороз // Стоматология. 2017. № 2. С. 82-98. Текст: непосредственный.

Статья поступила в редакцию 09.01.2021; одобрена после рецензирования 25.01.2021; принята к публикации 09.04.2021.

\section{A MODERN VIEW ON FLUOROSIS}

\section{Vyacheslav V. Namkhanov}

Cand. Sci. (Medicine), A/Prof.,

Dorzhi Banzarov Buryat State University

36a Oktyabrskaya St., Ulan-Ude 670002, Russia

namhanov@yandeex.ru

Yury L. Pisarevsky

Dr. Sci. (Medicine), Prof.,

Head of Prosthetic Dentistry Department

Chita State Medical Academy

163 Novobulvarnaya St., Chita 672038, Russia

ypisarevskij@mail.ru

Abstract. The article is devoted to the histopathological characteristics of dental fluorosis damaging of tooth enamel associated with constant and prolonged ingestion of excess fluoride in the body. It is noted that fluorosis is endemic and professional in nature. In severe cases, it is accompanied by damage to the hard tissue. Most often, fluorosis is observed during the eruption of permanent teeth, it practically does not occur in deciduous teeth. Fluorosis begins with whitish spots, which tinges yellow over the years. The article describes the main cause of fluorosis - low or high concentration of fluoride in water. The article analyzes the fluorine content in water sources of the Republic of Buryatia. We have described the modern methods of fluorosis treatment, their choice depends on the clinical manifestations in dentition.

Keywords: fluorosis, fluorine, facial skeleton, dentofacial system, maxilla, mandible, teeth, enamel, hygiene, oral cavity, inflammation, hard tissue

\section{For citation}

Namkhanov V. V., Pisarevsky Yu. L. A Modern View on Fluorosis. Bulletin of Buryat State University. Medicine and Pharmacy. 2021; 1: 58-61 (In Russ.).

The article was submitted 09.01.2021; approved after reviewing 25.01.2021; accepted for publication 09.04.2021. 